\title{
PERTUMBUHAN EKONOMI DALAM PERSPEKIF EKONOMI ISLAM
}

\author{
Zaenu Zuhdi \\ UIN Malang DPK di STAI Ma'had Ali Al-Hikam \\ Jln. Cengger Ayam 25 Malang, Telepon (0341) 495375/ HP. 081230586631
}

\begin{abstract}
The economic growth is one of the hot topics in macroeconomics. Through economic growth analysis a nation knows its development, wealth and prosperity. The growth is measured from income per head by indicating Gross National Product or Gross Domestic Product.

This research aims to explore the economics growth paradigm from Islamic perspective since there is a main different point of view between Economics in Islam and capitalism associated with the way of living. Capitalism underlines on how to complete the needs with unlimited effort, while in Islam the economic must be based on tauhid, rububiyyah, khalifah dan tazkiyah principles. Thus, in Islam perspective, prosperity is not all about material goods but also considering the happiness in life after the death.
\end{abstract}

Keywords: economic growth, prosperity and gross domestic product.

Untuk mencapai pada tingkatan pertumbuhan optimum, ada beberapa katagori yang harus ditempuh oleh sebuah negara agar dapat dikatagorikan pada negara yang mempunyai pertumbuhan pesat diantaranya adalah ada keseimbangan antara pertumbuhan penduuduk dengan tingkat produksi, kuatnya modal untuk sarana produksi, faktor produksi itu sendiri termasuk kekayaan negara, tanah dan lain sebagainya dan harus ada dukungan tehnologi yang memadai unutk dapat memproduksi seoptimal mungkin.

Ukuran pertumbuhan seperti dikemukakan diatas, adalah merupakan determinan dari pertumbuhan dalam ekonomi konvensional. Penulis akan mengulas secara singkat ukuran pertumbuhan dalam konteks ekonomi konvensional dan konsep Islam dengan metode komparasi. Langkah tersebut penulis ambil semata hanya ingin mengetahui sampai dimana 
persamaan dan perbedaan kedua konsep tersebut sehingga dapat dijadikan tolak ukur dalam kajian berikutnya.

Dalam ekonomi konvensional sering kita jumpai istilah Development, dan Growth, kedua istilah tersebut biasanya diartikan dengan perkembangan dan pertumbuhan ekonomi. Di sebagian literatur ada yang mengistilahkan "Development" dengan pembangunan ekonomi dan membedakan dengan "Growth" karena istilah pembangunan biasanya dipakai untuk analisis pertumbuhan pada negara-negara berkembang (Sukirno, 1996:415), dan akhirnya membentuk cabang ilmu tersendiri yang bermula dari kajian para ekonom terhadap negara-negara dunia ketiga yang masih miskin (Todaro, 1995:116).

Pada hakekatnya Development dan Growth, dalam penggunaanya dipakai dalam istilah yang berbeda pula. Dalam economic dictionary, kalimat development (perkembangan ekonomi) difahami sebagai proses trensmisi perekonomian yang melibatkan tranformasi struktural suatu perekonomian melalui industrialisasi (industrialization), peningkatan produk nasional bruto, (Gross National Product) dan pendapatan perkapita (income per head). Sedangkan Economic Growth (pertumbuhan economi) adalah pertumbuhan output riil suatu perekonomian sepanjang waktu. Pertumbuhan ekonomi biasanya diukur dengan peningkatan produk nasional bruto (Gross National Product) riil atau Produk Domestik Bruto (Gros Domestic Product). Sepanjang waktu, atau peningkatan pendapatan per kapita (income per head) sepanjang waktu (Pass, 1998:175-176). Dengan demikian perkembangan ekonomi adalah pertumbuhan perekonomian sebuah negara yang diikuti oleh perubahan-perubahan dalam struktur dan corak kegiatan ekonomi negara bersangkutan.

Meskipun kedua istilah tersebut biasanya digunakan dalam istilah yang sama, akan tetapi secara definitif mempunyai arti yang berbeda, karena development biasanya dipakai untuk menyatakan pertambahan output ekonomi sebuah negara, sedangkan growth digunakan untuk menjelaskan perkembangan standart keadaan materialnya dan membandingkanya dengan perekonomian-perekonomian yang lain (Sukirno, 1996:10).

\section{TEORI PERTUMBUHAN EKONOMI}

\section{Teori Klasik}

Pembahasan pertumbuhan ekonomi termasuk ruang lingkup pembahasan makro ekonomi. Persoalan pertumbuhan adalah termasuk diantara salah satu masalah serius yang 
dihadapi dan harus dipecahkan oleh penentu kebijakan dalam memikirkan ekonomi jangka panjang (Winardi, 1993:321). Oleh karena itu dibutuhkan teori yang dapat memaparkan kondisi pertumbuhan ekonomi di sebuah negara agar pertumbuhan yang diinginkan dapat diprediksi, karena melalui data-data pertumbuhan yang dilalui dapat diketahui laju pertumbuhan yang telah dicapai sehingga bagi pihak yang berkompeten dalam perekonomian termasuk pemerintah, mendapatkan informasi dan refrensi sebagai sarana dalam menentukan kebijakan.

Ada beberapa teori pertumbuhan ekonomi yang banyak dikemukakan oleh beberapa ekonom diantaranya adalah mazhab klasik. Teori ini pertama kali dilontarkan oleh Adam Smith dalam bukunya An Inquiry Into The Nature and Gauses of the Wealth of Nation dan The Wealth of Nations. Menurut pendapat mazhab klasik, pertumbuhan ekonomi dipengaruhi oleh empat faktor;
a. Jumlah penduduk
b. Jumlah stok barang-barang modal
c. Luas tanah dan kekayaan alam
d. Penggunaan teknologi

Dalam teori ekonomi mazhab klasik yang lebih banyak disorot adalah pengaruh pertumbuhan penduduk terhadap pertumbuhan ekonomi. Para ekonom klasik mengemukakan bahwa antara pendapatan per kapita dan jumlah penduduk harus sesuai/seimbang, kedua faktor tersebut akan saling mempengaruhi, karena apabila pertumbuhan penduduk rendah, maka produksi marjinal akan lebih tinggi daripada pendapatan perkapita. Pada saat itulah akan terjadi akumulasi modal yang menuntut pertambahan tenaga kerja sehingga fungsi produksi akan mengalami kenaikan (Winardi, 1993:321).

Menurut teori ini jumlah penduduk akan lebih memperbesar pendapatan dan akumulasi modal menuntut tenaga kerja baru untuk lebih meningkatkan produksi, walaupun pada akhirnya ketika jumlah penduduk semakin pesat maka hasil produksi marginal akan mengalami penurunan yang disebabklan oleh kelebihan tenaga kerja dan statisnya output riil. Oleh karena itu pendapatan nasional per kapita menjadi semakin lambat. Melalui asumsi tersebut, pertumbuhan penduduk yang semakin tinggi, pada akhirnya akan menyebabkan keadaan yang sama dengan pendapatan maksimum perkapita. Nah, pada waktu itulah pendapatan mencapai puncak optimal dan apabila digambarkan dalam bentuk kurva adalah; Kurva YPK menunjukkan tingkat perkapita dari berbagai jumlah penduduk dan $\mathrm{M}$ adalah 
puncak kurva tersebut, maka pendapatan optimal adalah jumlah penduduk sebanyak PO dan pendapatan perkapita paling maksimal adalah YO (Sukirno, 1996:431).

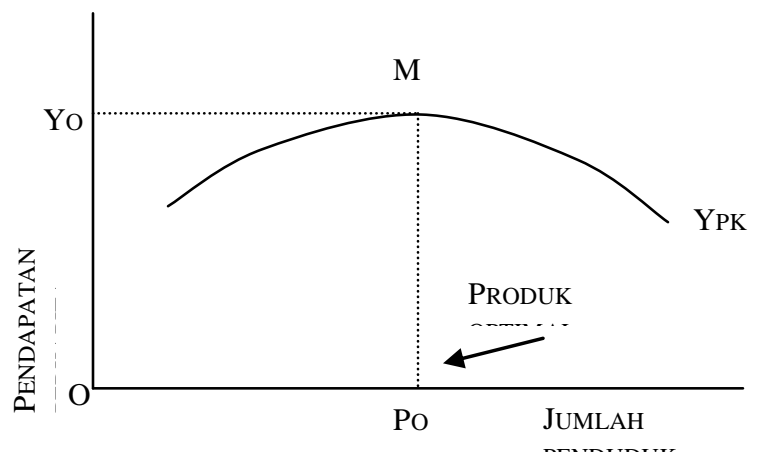

\section{Teori Malthus}

Teori ini pertama kali dikemukakan oleh Malthus (1798) sebagai pencetus pertama. Dalam teorinya ia mengatakan bahwa pertumbuhan jumlah penduduk lebih cepat dari alatalat subsistensi (bahan-bahan kehidupan). Jumlah penduduk cenderung bertambah cepat seperti ukuran 1,2,4,8,16,32 dan seterusnya, sedangkan alat-alat subsistensi bertambah menurut deret hitung 1,2,3,4 dan seterusnya, yakni pertumbuhanya lebih lambat dari pertumbuhan penduduk. Kondisi tersebut akan mengakibatkan penurunan pendapatan pekerja. Oleh karena itu pada akhirnya manusia akan megalami kemiskinan dan kesengsaraan kecuali dengan cara menekan laju pertumbuhan penduduk baik melalui :

a. Preventive checks (pencegahan preventeif) misalnya dengan melakukan perkawinan pada usia matang.

b. Positive Checks (pencegahan positif) misalnya adanya musibah perang atau penyakit (Winardi, 1993:330)

Maka akan muncul pertanyaan, bagaimanakah langkah positif untuk mencegah ledakan penduduk tersebut bagi malthusian. Diantara tawaran solusinya yang dikemukakan oleh mazhab ini pertama adalah melakukan perpindahan penduduk dari daerah yang padat pada daerah yang kurang penduduk. Kedua adalah megembangkan sumber daya baru serta teknikteknik produksi baru dengan tingkat kecepatan yang lebih tinggi dan memiliki tingkat pertumbuhan penduduk (Winardi, 1993:331)

\section{Teori Schumpeter}


Dalam Teori ini lebih menekankakan pada peran pengusaha dalam menciptakan pertumbuhan ekonomi. Pengusaha merupakan golongan yang akan terus menerus membuat pembaharuan atau inovasi dalam kegiatan ekonomi. Inovasi tersebut meliputi; memperkenalkan baranag-barang baru, efisiensi produksi barang, perluasan pasar, mengembangkan sumber bahan mentah dan megadakan perubahan-perubahan dalam organisasi perusahaan untuk mempertinggi efisiensi (Sukirno, 1996:433)

Analisis yang digunakan dalam teori ini adalah diumpamakan pada perekonomian yang sedang mandek, akan tetapi keadaan tersebut tidak berlangsung lama karena pengusaha akan mengadakan inovasi yang didorong oleh keinginan medapatkan keuntungan. Oleh karena itu mereka akan menambah modal baik dengan cara meminjam atau menanamkan kelebihan modalnya. Investasi baru tersebut pada akhirnya akan meningkatkan perekonomian negara dan secara otomastis pendapatan agregat meningkat sehingga tingkat konsumsi masyarakat akan bertambah pula. Oleh karena tingkat konsumsi bertambah maka akan mendorong pengusaha untuk menghasilkan lebih banyak barang dan melakukan penanaman modal baru. Akan tetapi pada saat kemajuan mencapai peningkatan tertinggi, saat itu pula pertumbuhan semakin lambat hingga akhirnya kembali pada keadaan tidak berkembang seperti semula (Sukirno, 1996:433)

Dari beberapa teori tersebut diatas pertumbuhan dalam konsep ekonomi klasik pokok pembahasannya tertuju pada dua variabel saja, yaitu faktor penduduk dan modal (Winardi, 1993:355). Pada tahap-tahap selanjutnya pengertian tentang pertumbuhan yang dikemukakan pada masa klasik ditafsirkan secara luas dan mempertajam analisisnya sehingga terjadi penyempurnaan yang disertai oleh perkembangan ekonomi itu sendiri. Penyempurnaan tersebut dilakukan oleh mazhab neoklasik yang analisisnya lebih ditekankan pada perkembangan faktor produksi (Sukirno, 1996:436), walaupun pada hakekatnya masih berangkat pada tesis yang sama yaitu pertumbuhan ekonomi pasti dipengaruhi oleh pertumbuhan dan produktifitas modal, dan produktifitas kerja serta perkembangan teknologi.

\section{TOLAK UKUR PERTUMBUHAN EKONOMI}

Sebelum melanjutkan pembahasan ini perlu kiranya mengambil kesepakatan tentang pengambilan istilah Developmet dan Growth, penulis akan mempergunakan istilah pertumbuhan untuk kemajuan dan perkembangan suatu negara dalam mencapai target pertumbuhan 
menurut definisi yang dibakukan oleh ekonomi konvensional, karena dari segi pengertian keduanya (development dan growth) mempunyai kesamaan arti, walaupun dalam studi ekonomi pembangunan istilah development lebih identik dengan perkembangan ekonomi di negaranegara berkembang sedangkan growth lebih bersifat umum.

Dalam sub bahasan ini penulis akan memaparkan beberapa faktor yang menjadi tolak ukur pertumbuhan ekonomi dari sudut pandang ekonomi konvensional. Karena konsep ekonomi konvesional (kapitalis) berdasarkan konsep materialistik-positivistik maka jelas mempunyai perbedaan dengan konsep Islam tentang pertumbuhan.

Ada beberapa faktor bagaimana sebuah negara dapat dikatakan tumbuh dan berkembang. Secara umum suatu negara dapat dikatakan berkembang apabila taraf hidup masyarakat terpenuhi dan secara agregat pendapatan per kapita negara terus meningkat (Sukirno, 1996:414).

Pendapatan negara dan taraf hidup masyarakat tidak akan terpenuhi apabila faktorfaktor yang menentukan pertumbuhan itu sendiri tidak berjalan dengan baik. Menurut Kuznez, suatu negara untuk mencapai pemenuhan kebutuhan dan peningkatan pendapatan dimungkinkan oleh adanya kemajuan tehnologi, kelembagaan dan perubahan ideologi (Todaro, 1995:121). Ketiga faktor tersebut mencakup beberapa aspek termasuk diantaranya telah dikemukakan para ekonom klasik diatas, yaitu tanah dan kekayaan alam lainnya, jumlah dan mutu dari penduduk dan tenaga kerja, jumlah stok barang-barang modal, serta penggunaan teknologi. Dari keempat faktor tersebut para ekonom modern menambahkan dengan pengaruh ideologi, sosial-politik serta sistem pasar yang luas sebagai sarana pertumbuhan ekonomi.

Dari beberapa aspek penentu pertumbuhan seperti telah penulis sebutkan diatas ada poin penting yang perlu di jelaskan lebih rinci diantaran adalah : Pertama adalah modal. Yang dimaksud modal disini adalah nilai riil neto seluruh barang modal produktif secara fisik milik negara termasuk diantaranya tanah, pabrik, mesin dan seluruh material yang dapat meningkatkan stok modal dan memungkinkan tercapainya peningkatan output, sehingga dapat dijadikan investasi pada masa yang akan datang, termasuk diantaranya investasi sumberdaya manusia.

Kedua pertumbuhan penduduk dan tenaga kerja. Walaupun pada tingkatan tertentu dapat menyebabkan persoalan, seperti pertambahan penduduk yang terlalu tinggi, akan tetapi 
apabila pertumbuhan penduduk seimbang dengan faktor produksi, apalagi didukung oleh tehnologi yang memadai, maka pertambahan penduduk tersebut akan mempercepat laju pertumbuhan (Todaro, 1995:116-118)

Ketiga kemajuan teknologi. Penggunaan teknologi sebagai faktor penunjang pertumbuhan menempati posisi penting, karena teknologi dapat membantu tugas tradisonal dalam usaha mencapai hasil maksimum. Contoh penggunaan tehnologi yang sederhana adalah mengganti bajak tradisional dengan bajak mesin sehinga lebih hemat modal dan kerja, sedangkan secara ekonomis akan lebih meningkatkan produktifitas.

Keempat ideologi, sistem sosial-politik, ideologi dan perilaku dalam kehidupan sosial juga ikut mempengaruhi pertumbuhan ekonomi suatu negara. Salah satu contoh adalah gagasan-gagasan untuk berperilaku lebih maju melalui penguasaan teknologi dan ilmu pengetahuan, ide-ide modernisme dan lain-lain. Atau melalui perombakan dalam sistem sosial seperti yang dapat mendorong pertumbuhan, misalnya penghapusan kekuasaan tuan tanah dan memberikannnya pada petani yang tidak memiliki tanah (Sukirno, 1996:427-428), ide-ide land reform yang pernah bergulir di Indonesia dan perubahan-perubahan lain yang dapat mempercepat pertumbuhan ekonimi.

Kempat karekteristik pertumbuhan ekonomi tersebut diatas, masing-masing saling berhubungan dan saling memperkuat satu sama lainnya. Apabila semua karakteristik tersebut dapat dilaksanakan secara keseluruhan, dalam konsep ilmu ekonomi konvensional, dimungkinkan akan mempercepat laju output per kapita, yakni pertumbuhan dapat dicapai melalui kenaikan produktivitas tenaga kerja, naiknya tingkat konsumsi, sehingga menimbulkan insentif yang dapat merubah struktur dan skala produksi yang berdampak pada struktur yang lain yang mendukung keempat karakter pemicu pertumbuhan ekonomi diatas. Kondisi tersebut juga akan merubah seluruh aspek, mulai dari organisasi, struktur ekonomi sebelumnya, sampai pada tatanan sosial dan politik.

Selanjutnya bagaimanakah cara untuk mengetahui apakah suatu negara telah mengalami pertumbuhan atau malah sebaliknya. Untuk menjawab pertanyaan tersebut indikator yang digunakan untuk menunjukkan tingkat kemakmuran dan pertumbuhan yang dicapai masyarakat suatu negara adalah dengan data pendapatan perkapita, yaitu pendapatan rata-rata penduduk (PNB) suatu negara pada suatu waktu tertentu, dengan menggunakan mata uang negara tersebut sebagai ukuran atau mengkonversikan PNB pada mata uang yang 
umum dipergunakan dalam transaksi internasional (misalnya dollar Amerika), supaya memungkinkan untuk dibuat perbandingan dengan negara lain (Sukirno, 1996:416)

Struktur Ekonomi Per kapita

Produk Nasional Bruto (\%)

\begin{tabular}{|lllll|}
\hline Nama Negara & US $\$$ & Pertanian & Industri & jasa \\
\hline $\begin{array}{l}\text { Negara-negara } \\
\text { berkembang }\end{array}$ & & & & \\
$\begin{array}{l}\text { Somalia } \\
\text { Mozambique }\end{array}$ & 120 & 65 & 9 & 26 \\
Nepal & 80 & 65 & 15 & 20 \\
India & 170 & 60 & 14 & 26 \\
Negara-negara maju & 350 & 31 & 29 & 40 \\
Inggeris & 16.100 & 2 & 36 & 62 \\
Jepang & 25.430 & 3 & 41 & 56 \\
Amerika Serikat & 21.790 & 2 & 29 & 69 \\
Jerman & 22.320 & 2 & 39 & 59 \\
\hline
\end{tabular}

Sumber : Cristhoper pass, Dictionary Of Economics, hal. 175.

\section{PERTUMBUHAN EKONOMI DALAM ISLAM}

Ada perbedaan dalam menilai pertumbuhan ekonomi antara Islam dengan konsep ekonomi kapitalis. Perbedaan tersebut berangkat dari sudut pandang yang berbeda tentang makna dan tujuan hidup. Berangakat dari konsep dasar kapitalis yang tujuan utamanya adalah pemenuhan kebutuhan materi tanpa batas, maka muncullah sikap pemenuhan terhadap barang-barang dan jasa tanpa batas pula. Lain halnya dengan Islam, walaupun memandang perlu materi, akan tetapi Islam tidak melupakan unsur moral-spritual dan tidak meletakkan 
materi sebagai tujuan utama, karena dalam ajaran Islam manusia tidak hanya akan menjalani hidup di dunia saja akan tetapi manusia akan dibangkitkan kembali kelak di akhirat. Sikap demikian sejak pertama sudah terintegrasi dalam kehidupan baik sosial, politik atau ekonomi (Mannan, 1997:379).

Bagi negara yang rata-rata menganut faham kapatalis, mereka lebih menitik beratkan pertumbuhan pada kemajuan dan kemodernan. Untuk mendapatkan status negara membangun, maju atau modern, sebuah negara hendaklah mampu dan menguasai sains dan teknologi. Di samping itu juga, negara tersebut hendaklah mampu mewujudkan sektor perindustrian dan perusahaan.

Pemakaian tolak ukur demikian, karena bagi mereka melalui perindustrian dan perusahaan-lah ekonomi negara akan berkembang, pembangunan industri akan bertambah pesat, peluang-peluang pekerjaan dapat disediakan dan kemiskinan dapat dikurangkan. Namun apa yang menjadi asas kepada konsep pertumbuhan mereka adalah kapital sebagai penggerak dan ukuran pertumbuhan.

Perbedaan yang paling utama antara konsep pertumbuhan dalam Islam dan konvensional adalah terletak pada asas yang dipakai, dalam Islam unsur spritualitas (agama) menjadi prioritas utama. Arti agama disini adalah ajaran agama yang termanifestasi dalam alQur'an dan sunnah Rasul. Meskipun prinsip pertumbuhan (ekonomi) dalam Islam berlandaskan al-Qur'an dan al-Hadith, namun ia tidak merinci secara detail yang menyangkut masalah-masalah tekhnis, akan tetapi hanya menjelaskan secara global yang mencakup petunjuk-petunjuk pokok, kaidah-kaidah, prinsip dan canbang-cabang penting yang bersifat spesifik, karena masalah ekonomi termasuk masalah kemanusiaan yang dapat mengalami perubahan sesuai dengan lingkungan dan zamannya, sedangkan masalah yang bersifat tekhnis diselesaikan melalui upaya manusia (ijtihad) sesuai kondisi lingkungan dan zamannya (Rohayana, 2000:3)

Adapun asas-asas pertumbuhan dalam Islam ada empat yaitu :

1. Tauhid

Konsep tauhid adalah menjelaskan hubungan sesama manusia dengan Allah. Manusia harus patuh pada Allah SWT, kepatuhan manusia kepada Allah dilihat dari tingkah laku atau tindakan mereka mematuhi perintah Allah dan meninggalkan larangan-Nya dengan cara yang ikhlas dan menyeluruh. 
2. Rububiyyah

Konsep yang menerangkan sifat Allah. Sifat Allah adalah sebagai penguasa di alam ini. Dia yang berkuasa membuat peraturan untuk menjamin dan membimbing kehidupan manusia supaya sempurna dan sejahtera. Dia juga berkuasa untuk menjaga, mengawal, menampung dan mengurus kehidupan makhluk ke arah kesempurnaan.

3. Khalifah

Manusia sebagai utusan Allah di muka bumi ini. Tanggung jawab utamanya ialah sebagai pemegang amanah Allah dalam segala aspek seperti akhlak, ekonomi, politik dan sosial. Sebagai pemegang amanah, manusia tidak boleh merusak alam ini. Pembangunan yang hendak dijalankan adalah memberi kebaikan seperti yang ajarkan oleh Allah melalui nabi-Nya. Oleh karena itu, manusia wajib menghindari dari melakukan pembangunan dapat merusak, yaitu pembangunan yang membawa kepada keruntuhan, kekacauan dan kezaliman/tidak adil.

Asas terpenting untuk melaksanakan tugas khalifah selain daripada iman ialah ilmu. Ilmu yang dimaksudkan ialah ilmu tentang realitas fisik. Merubah kepada kedudukan ilmu tersebut berarti telah mengubah kedudukannya yang asli dan perubahan yang dilakukan menyalahi sunnatullah maka ilmu tersebut akan merusak bukan memperbaiki.

4. Tazkiyah

Tazkiyah merupakan mekanisme utama bagi mewujudkan pertumbuhan termasuk sumber daya manusia. Tazkiyah melibatkan proses penyucian dinamik yang perlu dilakukan oleh setiap umat manusia sekiranya dia mempunyai keinginan untuk maju dan sejahtera. Manusia perlu menyucikan hubungan antara dirinya dengan Allah, manusia dengan manusia dan makhluk lain di dunia (Ahmad, 1980:178)

Keempat asas tersebut di atas merupakan pijakan utama yang mempunyai nilai etika bagi manusia dalam melakukan pembangunan dimuka bumi, karena keempat asas tersebut sudah mencakup seluruh aspek kebutuhan manusia baik materi atau spritualitas sebagai ciri khusus ekonomi yang berlandaskan ajaran syari'ah.

\section{KESIMPULAN}

Apa yang membedakan antara faham kapatalisme dengan Islam dalam konsep pertumbuhan ?. Imam Al-Ghazali menyatakan bahwa pertumbuhan dalam Islam mencakup 
tiga aspek penting yaitu pembangunan fisik, mental dan spiritual. Sedagkan menurut Heidar Naqvi pertumbuhan dalam kerangka Islam meliputi aspek moral-spiritual dan material kehidupan manusia dengan rincian berikut :

1. Tuntutan umum Islami untuk menjamin dan mengamankan pendistribusian pendapatan (kemakmuran) secara adil dan menetapkan batas dalam tingkat pertumbuhan yang layak.

2. Mempertahankan equitas antar generasi. Karena pembentukan modal harus di seimbangkan dengan pembentukan modal sumber daya manusia tangguh yang merupakan investasi jangka panjang (Naqvi, 1991:140)

Selain itu jika lihat dari sudut ekonomi, pertumbuhan menurut sistem kapitalis Barat dimana riba masih dijadikan sistem baik dalam bank dan perdagangan adalah sesuatu yang bertentangan dengan konsep Islam. dalam al-Qur'an di sebutkan:

"Hai orang-orang yang beriman, bertakwalah kamu kepada Allah dan tinggalkan sisa riba (yang belum dipungut) jika kamu orang-orang yang beriman. Maka jika kau tidak mengerjakannya, maka ketahuilah bahwa Allah dan rasul-rasulnya akan memerangi kamu..."

"Orang yang memakan riba tidak boleh berdiri (pada hari kiamat ) melainkan seperti berdirinya orang yang dirasuki setan..." (Al Baqoroh;275)

Jadi Islam menawarkan konsep keseimbangan antara tujuan duniawi dan ukhrawi. Konsep keseimbangan ini pula yang melandasi ajaran Islam tentang optimalisasi pertumbuhan, karena pertumbuhan yang ditawarkan ekonomi konvensional pada akhirnya mengundang pertanyaan dengan tidak efisiensinya distribusi pendapatan dan dalam memacu pertumbuhan yang pada akhirnya kembali pada ketidak seimbangan (Naqvi, 1991:136)

Di antara komponen yang dapat memacu pertumbuhan juga di antaranya adalah terpenuhinya kebutuhan melalui kesempatan kerja penuh (full empoyment). Syari'ah menganjurkan setiap manusia untuk memenuhi kebutuhan dasarnya untuk kesejahteraan hidupnya. Penggunaan sumberdaya manusia merupakan keharusan bagi manusia untuk kesejahteraan dirinya termasuk di antara tujuan syari'ah, demikian juga pendayagunaan sumber daya alam sebagai bahan untuk mendapatkan hasil yang lebih besar, akan tetapi Islam juga melarang menghambur-hamburkannya (Chapra, 1997:5) 
Selain dorongan-dorongan spiritual dan nilai yang multi dimensional dalam ajaran Islam diantaranya adalah nilai humanitas (humanity) yang tercermin dalam sikap takaful atau tadamun (keamanan sal bersama). Sikap ini secara aktual dapal terimplementasikan melalui zakat, pinjaman untuk kebajikan, shadakah dan lainnnya yang dapat memotivasi pertumbuhan ekonomi (Mannan,1997:379). Perbuatan tersebut apabila dilandasi dengan kesadaran yang tinggi terutama bagi orang yang mempunyai kelebihan harta tentu akan mendorong pendapatan perkapita negara karena akan mendorong konsumsi dan distribusi per individu.

\section{DAFTAR PUSTAKA}

Sukirno, Sadono. 1996. Pengantar Teori Makroekonomi. Jakarta: Raja Grafindo Persda.

Todaro, Michael T. 1995. Pembangunan Ekonomi di Dunia Ketiga, Jilid I. Jakarta: Erlangga.

Pass, Cristhoper. 1998. Dictionary Of Economic (second edition). Jakarta: Erlangga.

Winardi. 1993. Sejarah Perkembangan Ilmu Ekonom. Bandung: Tarsito.

Mannan, M. A. 1997. Teori dan Praktek Ekonomi Islam, terj. M. Nastngin. Yogyakarta: Dana Bhakti Wakaf.

Rohayana, Ade Dede. 2000. Ekonomi Islam Pendekatan al-Qur'an dan Hadith. Religia Vol. 3, No. 1 (Februari).

Ahmad, Khursid. 1980. Economic Development In Islamic Framework. Liecester : The Islamic Fondation.

Naqvi ,Nawab Heider. 1991. Etika Dan Ilmu Ekonomi. Bandung: Mizan.

Chapra, M. Umer. 1997. Al-Qur'an menuju Sistem Moneter Yang Adil. Yogyakarta: Dana Bhakti Wakaf. 